\title{
Effects of oxen yoke and donkey collar on traction force and their consequences on sorghum production in the northern Burkina Faso
}

\author{
Albert BARRO $^{1 *}$, Clarisse Pulchérie KONDOMBO ${ }^{2}$ and Barthélémy YELEMOU ${ }^{1}$ \\ ${ }^{I}$ INERA, Programme GRN/SP centre, DRREA du centre, BP 10 Koudougou, Burkina Faso. \\ ${ }^{2}$ INERA, Programme CT, DRREA du centre, BP 10 Koudougou, Burkina Faso. \\ *Corresponding author; E-mail: altbarro@yahoo.fr; BP 10 Saria/Koudougou; Tel: (00226) 70100310
}

\begin{abstract}
The realization of mechanized zaï with draft animal encounters the weakness of hitch traction capabilities. To overcome this issue, a study was conducted in three villages in the northern Burkina Faso with the aim at evaluating the effect of improved yoke and improved collar respectively with oxen and donkey harnessing on the traction force delivered. The experimental design was a simple randomized bloc comparing improved yoke to classic yoke and improved collar to classic collar. The results showed that the improved yoke allows oxen harness to get $57 \%$ more traction force compared with the harness of classic yoke which was 53 $\mathrm{daN}(\mathrm{P}<0.0001)$. For the donkey harness there was no statistical difference between the improved collar and the classic one ( $24 \mathrm{daN}$ and $23 \mathrm{daN}$ ). Tillage quality was better with the improved yoke and generates more soil roughness index. This led to increase in sorghum grain yield by $60 \%\left(694 \mathrm{~kg} \cdot \mathrm{ha}^{-1}\right)$ and sorghum straw yield increase by $91 \%\left(2688 \mathrm{~kg} \cdot \mathrm{ha}^{-1}\right)$. The improved yoke increases oxen traction force, dry soil tillage efficiency and sorghum production. These results showed that improved yoke can contribute to an increase in sorghum yield in the northern Burkina Faso.
\end{abstract}

(C) 2017 International Formulae Group. All rights reserved.

Keywords: Sahel, animal, harness, traction, force, sorghum.

\section{INTRODUCTION}

In many regions of Africa, draft animal is an essential part of farming systems (FAO, 2008; Lhoste et al., 2010). In the Sahelian zone where drought is an important constraint on crop production, farmers often used dry soil tillage to be able to have earlier moisture for sowing. That is the case in the northern Burkina Faso, where zaï is used for sorghum and millet cropping (Sawadogo et al., 2008). To alleviate the labor time for people, the manual zaï have been mechanized (Barro et al., 2005). But the draft force delivered by the most common animals (oxen and donkeys) used for work remains weak (Lëtzebuerger, 2004). The sowing period and plant growth stage are very important in the rainfed production, because it largely determines the success of the production. In the northern Burkina Faso, the rains settle down late and that leads to a delay in the crops establishment (Zougmoré et al., 2004). The droughts of the 70 s have led authorities and the international community to implement water management 
practices in the watershed by the systems of rock bunds and grass strips (Zougmoré et al., 2004; Kiéma et al., 2012) and in the plot level by zaï, half-moons, mulching, etc. Water management led to an improvement of the production which can only be maintained if their suitable combination is made with adequate fertilization for poor soil mineral elements. Thus, production techniques involving the management of water and nutrients across the land have been developed, improved and disseminated in the central and the northern region of Burkina Faso (Zougmoré et al., 2002). Zaï association with mineral fertilization by micro dose led to an increase in sorghum grain and straw production (Palé et al., 2009; Barro et al., 2011; Kate et al., 2016).

However, the use of animal traction for mechanized zaï realization during the dry season is facing several constraints, including weak traction capacity of oxen and donkeys because of their bad harnessing.

To overcome this limiting factor, a study of oxen and donkeys harnessing was conducted from 2008 to 2010 in the northern part of Burkina Faso to identify the better harnessing that improve draft capacity for oxen and donkeys. This study compared a classic yoke to an improved one for oxen, and a classic collar to an improved one for donkeys. The draft force for dry soil tillage was measured. Sorghum straw and grain yields were also evaluated.

\section{MATERIALS AND METHODS Experimental sites}

The studies have been conducted in the northern Burkina Faso in three villages (Salla, Kibilo and Pougyango). The village of Salla is in Lorum province (Titao), whose coordinates are $13^{\circ} 47^{\prime} 36.83^{\prime \prime} \mathrm{N} ; 2^{\circ} 6^{\prime} 5.16^{\prime \prime} \mathrm{W}$; the village of Kibilo is in Zondoma province (Gourcy), at $13^{\circ} 12^{\prime} 38.33^{\prime \prime} \mathrm{N} ; 2^{\circ} 15^{\prime} 32.81^{\prime \prime} \mathrm{W}$, and the village of Pougyango is in Passoré province (Yako). It is located at $12^{\circ} 58^{\prime} 35.82^{\prime \prime} \mathrm{N} ; 2^{\circ} 09^{\prime} 55.82^{\prime \prime} \mathrm{W}$. The average annual rainfall varied from 600 $\mathrm{mm}$ in the North (Salla) to $700 \mathrm{~mm}$ in the South (Yako) (Figure 1).

\section{Soils and vegetation}

The major type of soil is ferric lixisol (FAO, 2006). This soil covers an important part of the country (Zougmoré et al., 2008). The soil is not deep; in average it is $50 \mathrm{~cm}$ depth. The slope is low $(0.8 \%)$ and in general soil texture is sand and loam (Table 1). In this study, there are three major types of soil texture. The moisture measurement was made on the layers 0-10 and 10-20 cm (Table 2).

The natural vegetation was bush Savanah with the following species Combretum spp. and Vitellaria paradoxa Gaertn. f. The herbaceous layer is composed mainly of Loudetia togoensis (Pilger) C.E. Hubb. and Schoenfeldia gracilis Kunth. In the South, the natural vegetation is degraded because of human activities. Now the savanna is composed of trees and shrubby. We can find there, Vitellaria paradoxa Gaertn. f, Faidherbia albida Del, Parkia biglobosa (Jacq.) Benth., Tamarindus indica Linn., Lannea acida A. Rich. and Lannea microcarpa Engl. and K. Krause Bombax costatum Pellegr and Vuillet, etc. The herbaceous layer is mainly constituted of Andropogon gayanus Kunth, Pennicetum pedicelatum Trin, Loudetia togoensis (Pilger) C.E. Hubb, which are annual (Arbonnier, 2002).

\section{Material of study \\ Yokes and collars}

The improved yoke is a material of hitch that allows a pair of oxen to have a better traction force. The forms of this 
harnessing tool are rounded and the contact with the animal is ensured by cushions (Figure 2). The cord allows adjustment on the neckline of the animals so that there is no strangulation. The classic yoke is round or parallelepiped timber perforated at the sides of oxen neckline position. In the holes of the timber is set an iron bars or cords adjustable to the neckline of animals, and sometimes the wood is summarily pruned and has acute angles. However, there is never a cushion on the classic yoke (Figure 3).

Donkey improved collar and donkey classic collar are presented on Figures $4 \mathrm{a}$ and $4 \mathrm{~b}$. The donkey improved collar is a wood support, adapted to the neckline of the donkey and covered with a cushion on the sides (Figure 4a). The donkey classic collar has a support wrapped or not, by rags (Figure $4 \mathrm{~b}$ ).

The tool used is oxen plow frame. On this frame, a tine IR12 for dry soil tillage has been assembled by a shore. The mechanized zaï is done by the method described by Barro et al. (2005). The tool for realization of the mechanized zaï is drawn by oxen or donkeys harness. For plots having received the mineral fertilization (14 N-23 P-14 K) by micro dose, the level is $2 \mathrm{~g} /$ pit $\left(65 \mathrm{~kg} \cdot \mathrm{ha}^{-1}\right), 14$ days after the emergence.

\section{Crop and experimental design}

The plant material used in this study was Sorghum bicolor L. Moench. with Kapèlga (SCHV 168), an improved local variety, with short cycle (90 days).

The experimental design was a simple randomized bloc with two replications by site. The plot is $30 \mathrm{~m}$ length and $10 \mathrm{~m}$ width. The sowing was made at $80 \mathrm{~cm}$ intervals between rows and $40 \mathrm{~cm}$ between planting holes in a row. The thinning was done at two plants per hole around 14 days after emergence.

\section{Data collected \\ The traction force}

The traction effort was measured using a mechanical dynamometer with maxima mounted between the soil tillage tool and oxen or donkeys at the rate of 30 repetitions by treatment. The texture of the soil was determined by Robinson method with three samples of each site in $0-20 \mathrm{~cm}$ layer. Soil moisture content was measured by taking samples in 0-10 and 10-20 cm layers. Three replications were made in the plots before tillage.

\section{The soil roughness}

Soil roughness was measured by the method of the chain (Jester et al., 2005). The chain is laid on the soil surface so that it follows soil micro-relief. The chain was 1.045 $\mathrm{m}$ length (L). The measurements were done cross the zai pits. The vertical projection of the chain (lo) is then measured with 30 replications. The roughness index (Irug) is the ratio L/lo.

\section{The pits sizes and sorghum yield}

The size of zaï pits was measured using a rigid meter at the rate of 30 repetitions by treatment. The pits were chosen randomly on the whole plot except the borders pits. The width of the pit was measured on the axis passing through the center and making $45^{\circ}$ with each furrow and the depth was also measured. Sorghum grain and straw yields were measured on each plot.

The regression model and variance analysis of XLSTAT software, version 2015.17.6 (Addinsoft 2015), were used for data analysis. 


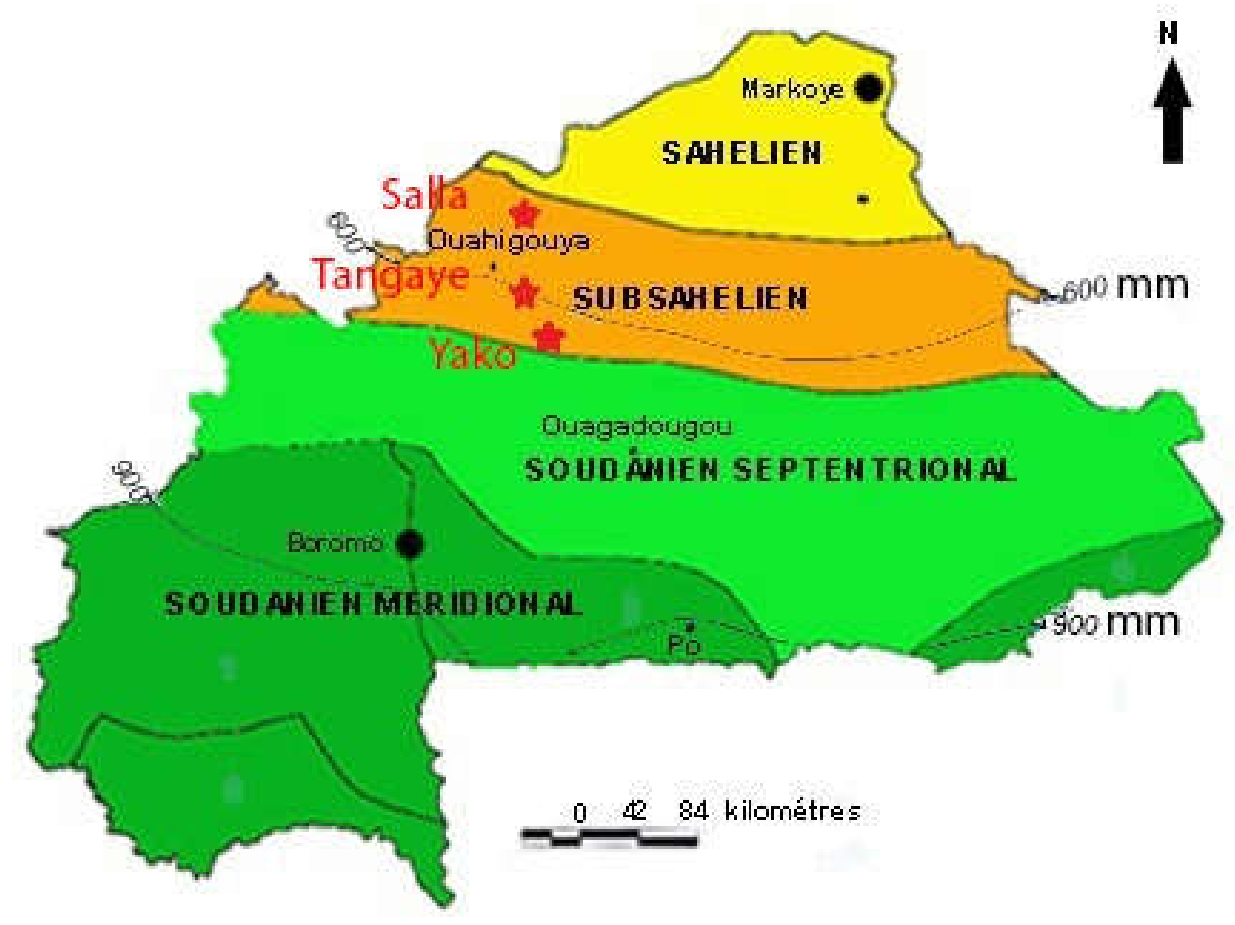

Figure 1: Map of the study areas (Guinko 1995 cited by http://ornithologieetbetta.free.fr/ ornitho/ornitho_burkina_pays.php, 2010).

Table 1: Soil texture in the studies sites (\%).

\begin{tabular}{lcccc}
\hline Sites & Clay & Silt & Sand & Soil type \\
\hline Salla & 46.1 & 23.0 & 30.9 & clayey \\
Kibilo & 5.5 & 6.5 & 88.0 & sandy \\
Pougyango & 24.8 & 44.3 & 30.9 & Loam clay-sandy \\
\hline
\end{tabular}

Table 2: Soil moisture at tillage period (\%).

\begin{tabular}{lcc}
\hline Sites & Soil layer $\mathbf{( 0 - 1 0} \mathbf{~ c m})$ & Soil layer $\mathbf{( 1 0 - 2 0 ~ c m ) ~}$ \\
\hline Pougyango & 1.24 & 1.81 \\
Salla & 1.53 & 2.05 \\
Kibilo & 1.70 & 1.87 \\
\hline
\end{tabular}




\section{0 to $90 \mathrm{~cm}$ for plowing}

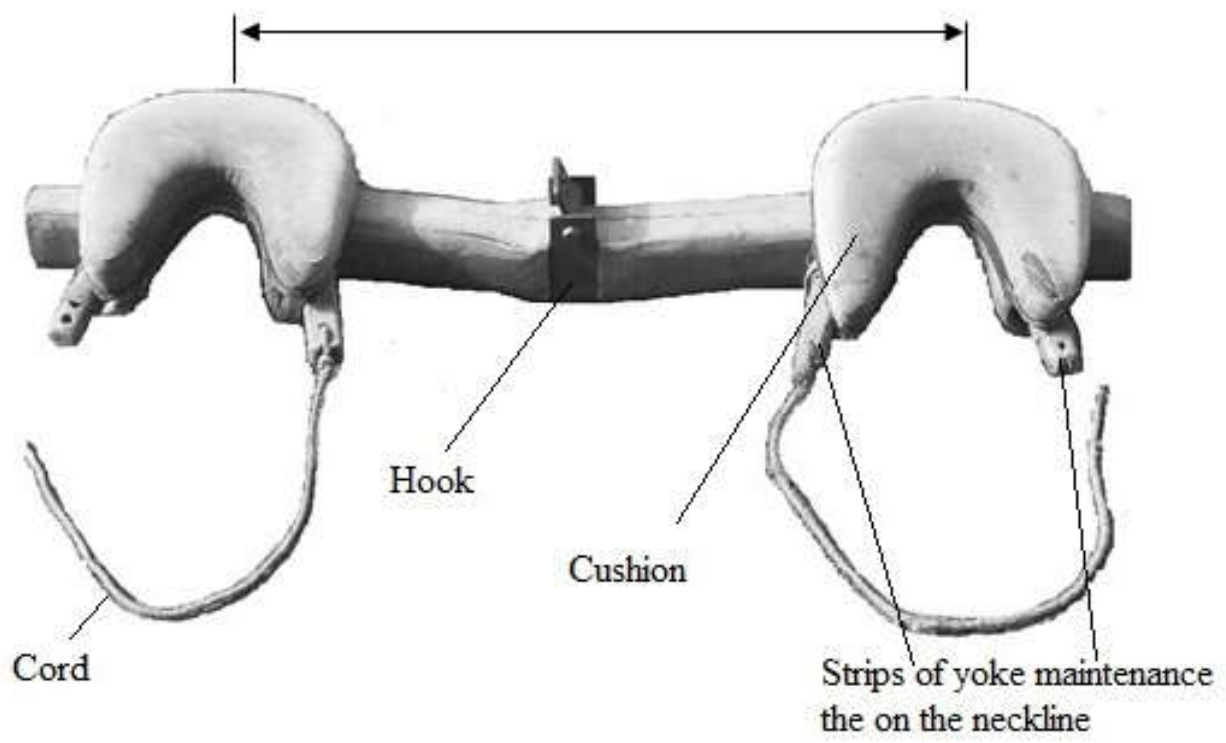

Figure 2: Improve yoke (photo Barro 2005).

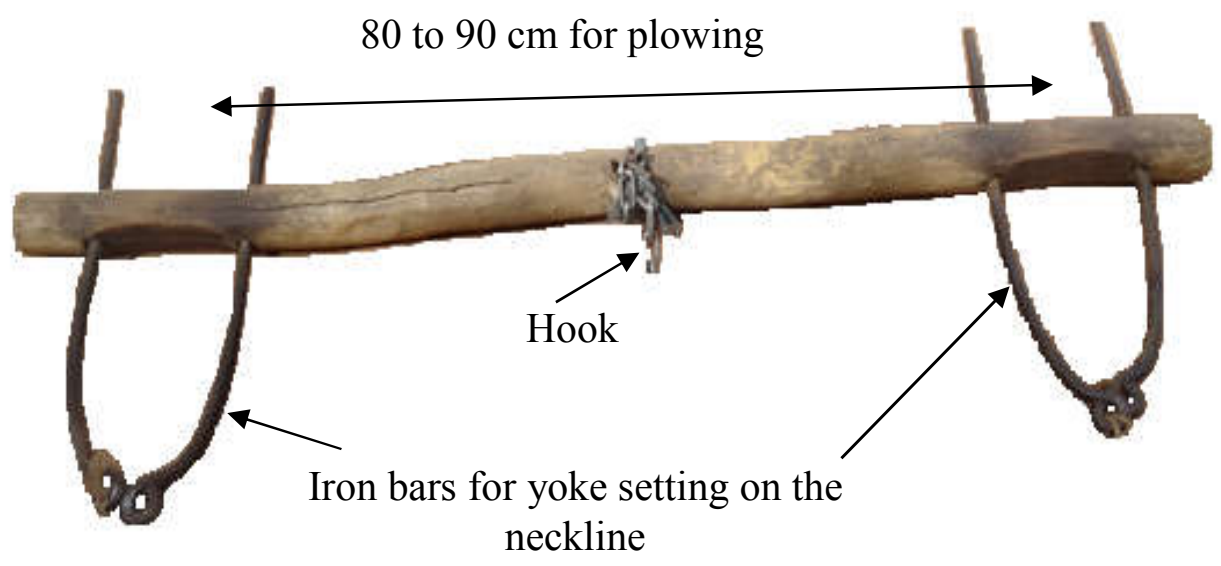

Figure 3: Farmer's classic yoke (photo Barro 2005). 
a: improve collar

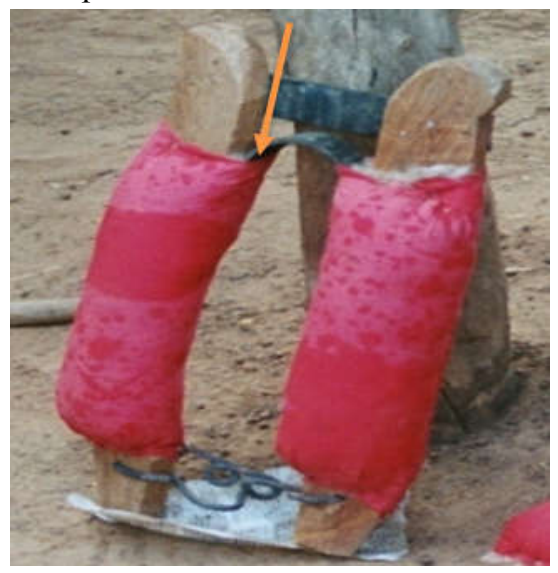

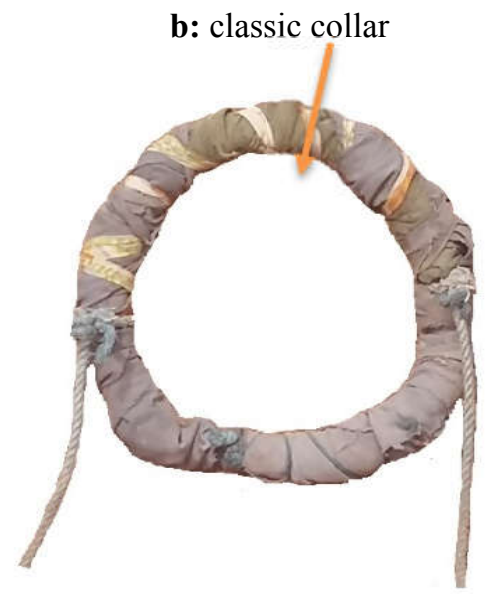

Figure 4: a) improve collar for donkeys; b) classic collar for donkeys (photo Barro 2005).

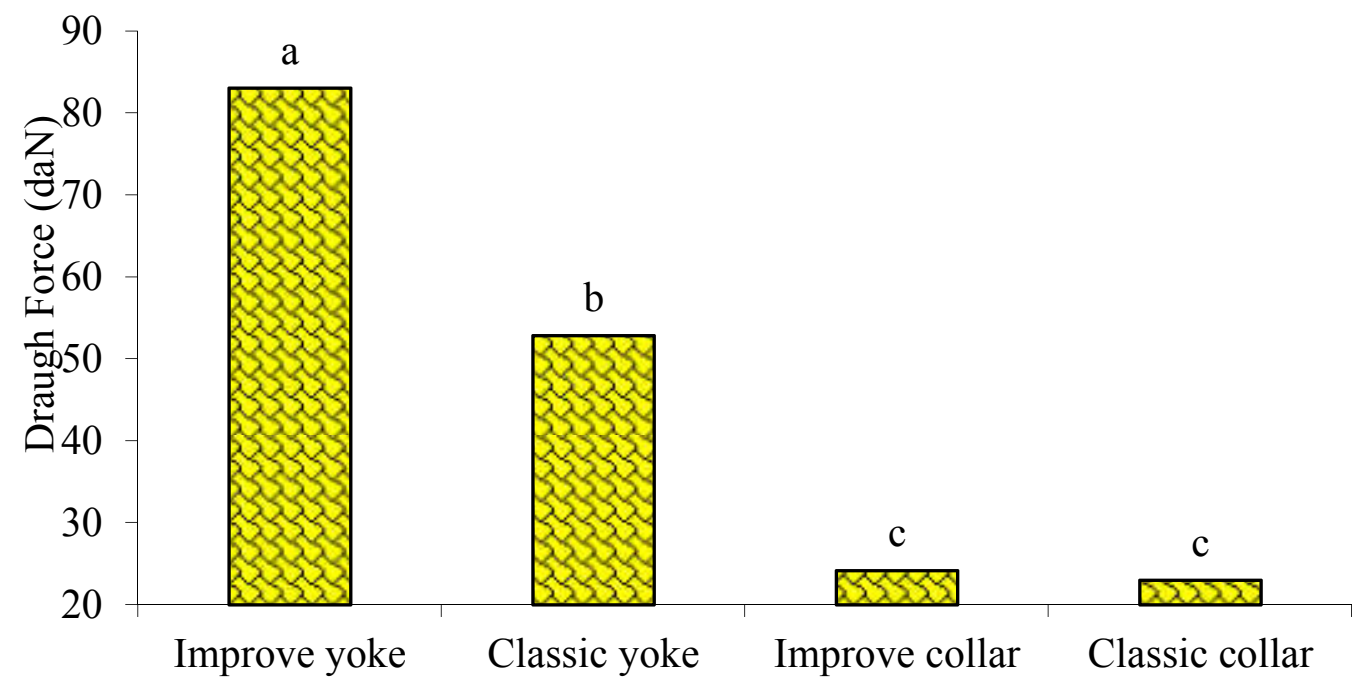

Figure 5: Traction force variation according the type of harnessing. $\mathrm{N}$ and $\mathrm{K}$ test: a, b, c, are groups of means significantly different at $\alpha=0.05$ level. 


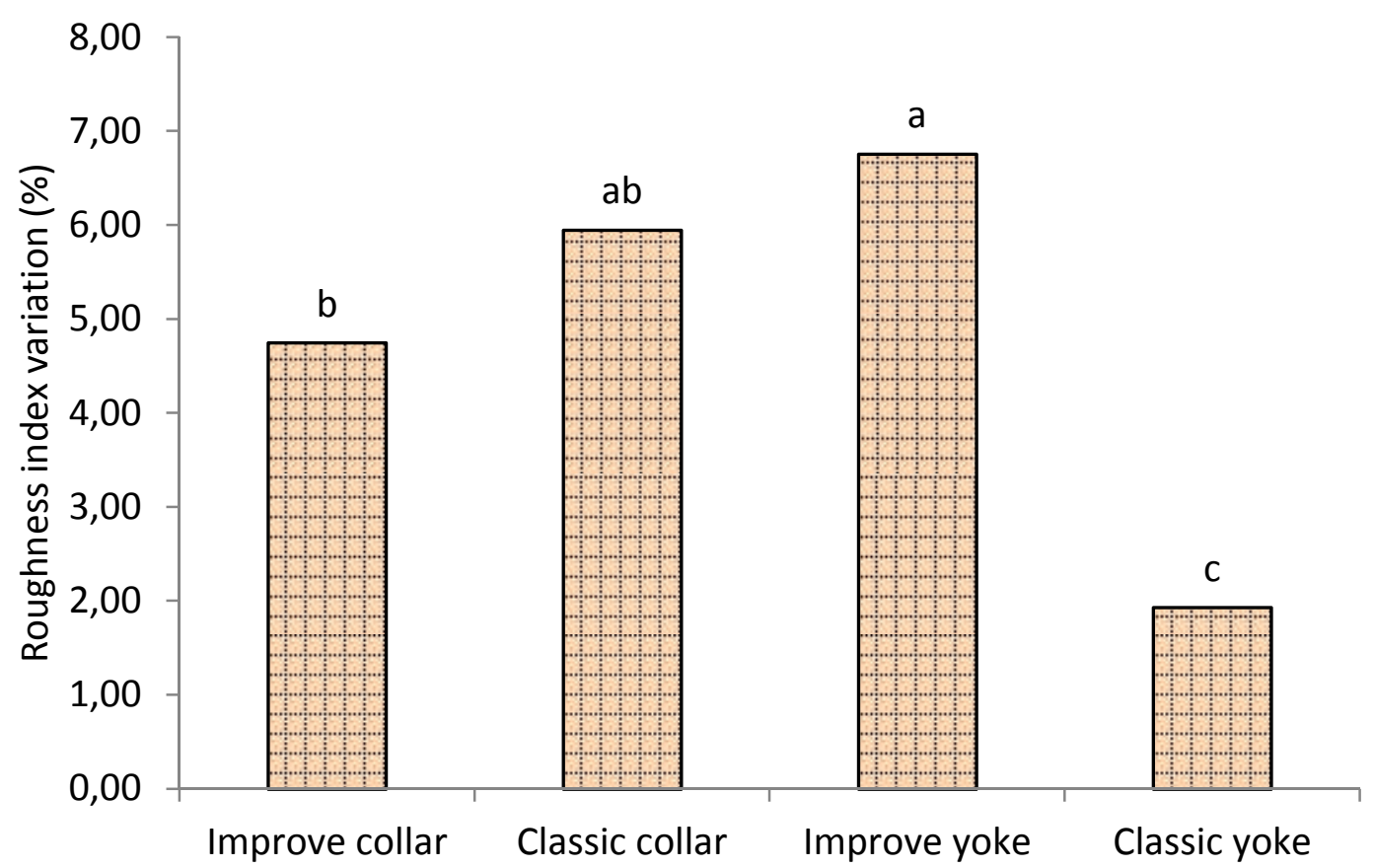

Figure 6: Soil roughness index variation after the tillage. $N$ and $K$ test: a, ab, b, c, are groups of means significantly different at $\alpha=0.05$ level.

\section{RESULTS}

\section{Traction force}

The variance analysis on the traction forces measured on the yokes and collars showed a highly significant difference between means $(P<0.0001)$. The greatest traction force is provided by oxen harness with improved yoke ( $83 \mathrm{daN})$. It is followed by oxen harness with the classic yoke which has a traction force means of $53 \mathrm{daN}$. The high traction force delivered by improved yoke is $57 \%$ more than those provided by the oxen harness with the classic yoke (Figure 5). The means of traction forces of donkey harness are lower than those of oxen harness. Between the donkey harness with classic collar and those with the improved one, there is no significant difference (23 and $24 \mathrm{daN})$.
The analysis of soil roughness after tillage showed significant differences between the hitches (Figure 6). The effect of these traction forces on the soil roughness indicates that plots having tillage by oxen harness with improved yoke have presented the most roughness increase $(6.76 \%)$. The plots having tillage by donkey harness with the improved collar have more great roughness increase $(5.95 \%)$ than those of donkey harness with the classic collar $(4.75 \%)$. The lowest roughness increase value is observed on the plot having tillage with oxen harness by classic yoke $(1.93 \%)$.

\section{Roughness index and pits sizes}

Pits sizes variance analysis shows that there is a significant difference between the means of the widths and depths of pits for the 
four treatments (Table 3). The greatest width and depth are obtained after the tillage with improved yoke harness. The improved donkey collar tillage gives pits depth identical to that of the classic collar, but the width of the zaï pit which is $4 \mathrm{~cm}$ lower is given by the classic yoke. The classic yoke tillage generates similar pits width to that of the improved yoke, but the depth is $1 \mathrm{~cm}$ lower. The working depth has a strong relationship with roughness index increase. The probability is 0.01 at $\alpha=0.05$ level with a linear regression (Figure 7 a). The value of the regression slope (1.6) is positive. The depths of 9 to $10 \mathrm{~cm}$ correspond to the high value of roughness index increase. The roughness index increase after the tillage is also linked to the pits width (Figure $7 \mathrm{~b}$ ) with a probability of 0.03 at $\alpha=$ 0.05 level. The regression is slightly positive (slope $=0.37$ ). The values of 30 to $35 \mathrm{~cm}$ of pits width correspond to the high roughness index increase.

\section{Sorghum yield}

The sorghum grain and straw production measured on plots treated with the improved yoke and the classic yoke showed highly significant different means $(\mathrm{P}<$ 0.0001 ) according to the presence or not of mineral fertilizers by micro dose (Figures 8 a and 8 b). With NPK mineral fertilizer by micro dose, the use of harness with the improved yoke gave an average grain yield of $1835 \mathrm{~kg} \cdot \mathrm{ha}^{-1}$ against $1141 \mathrm{~kg} \cdot \mathrm{ha}^{-1}$ for the classic yoke. In the absence of mineral fertilizer by micro dose, the use of the harness with the improved yoke and classic yoke gave respectively $1165 \mathrm{~kg} \cdot \mathrm{ha}^{-1}$ and $704 \mathrm{~kg} \cdot \mathrm{ha}^{-1}$ of grain yield. The sorghum grain yield obtained with the improved yoke harness without micro dose is statistically similar to the classic yoke with micro dose. The straw production follows the same trends. With micro dose fertilization, the straw production level of the plots having improved yoke tillage is practically the double of those obtained by classic yoke (5646 and $2958 \mathrm{~kg} \cdot \mathrm{ha}^{-1}$ ).

Table 3: Zaï pits sizes (width and depth) by harness system.

\begin{tabular}{lcc}
\hline Treatments & width $\mathbf{( c m )}$ & depth $(\mathbf{c m})$ \\
\hline Improve yoke & $32.9 \mathrm{a}$ & $9.9 \mathrm{a}$ \\
Classical collar & $29.4 \mathrm{a}$ & $8.2 \mathrm{~b}$ \\
Improve collar & $25.2 \mathrm{~b}$ & $7.7 \mathrm{~b}$ \\
Classical yoke & $23.3 \mathrm{~b}$ & $6.5 \mathrm{c}$ \\
Probability & $<0.0001$ & $<0.0001$ \\
\hline
\end{tabular}

$\mathrm{N}$ and $\mathrm{K}$ test: $\mathrm{a}, \mathrm{b}, \mathrm{c}$, are groups of means significantly different at $\alpha=0.05$ level 


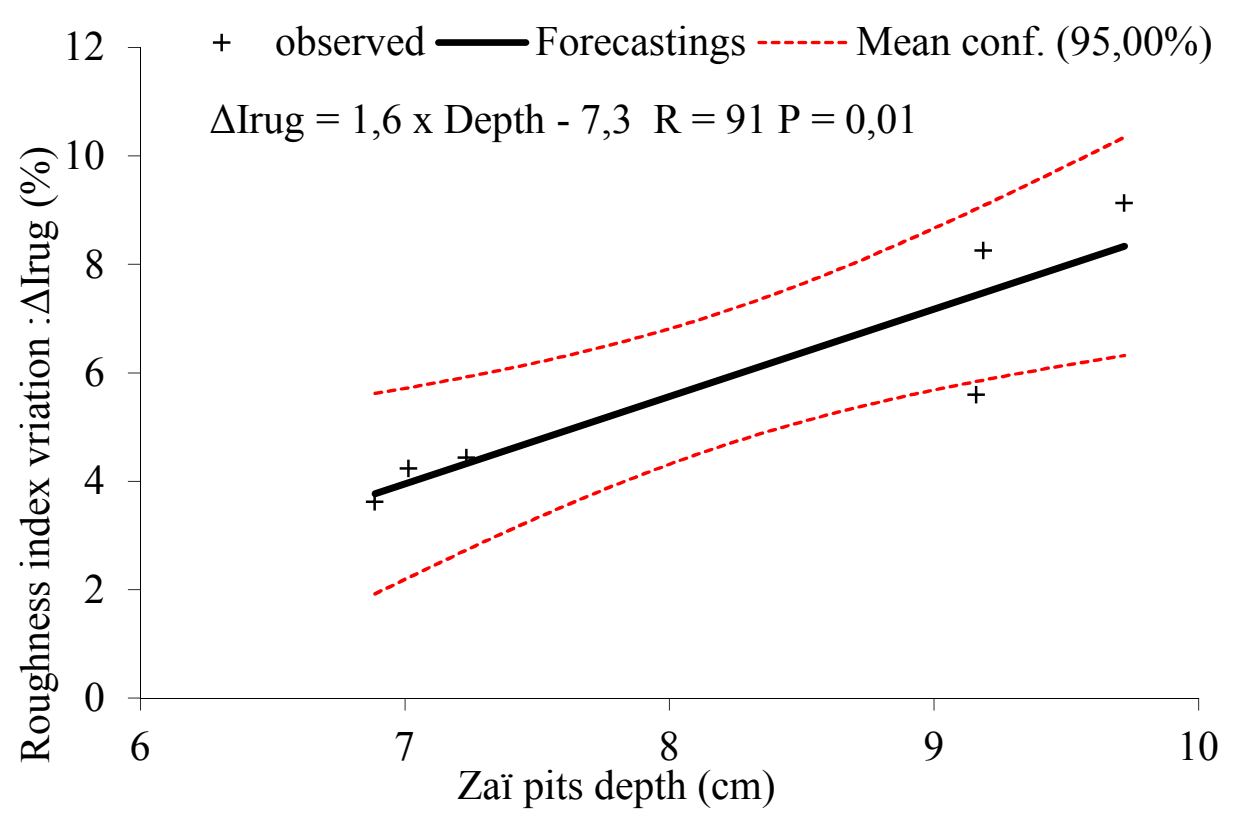

a)

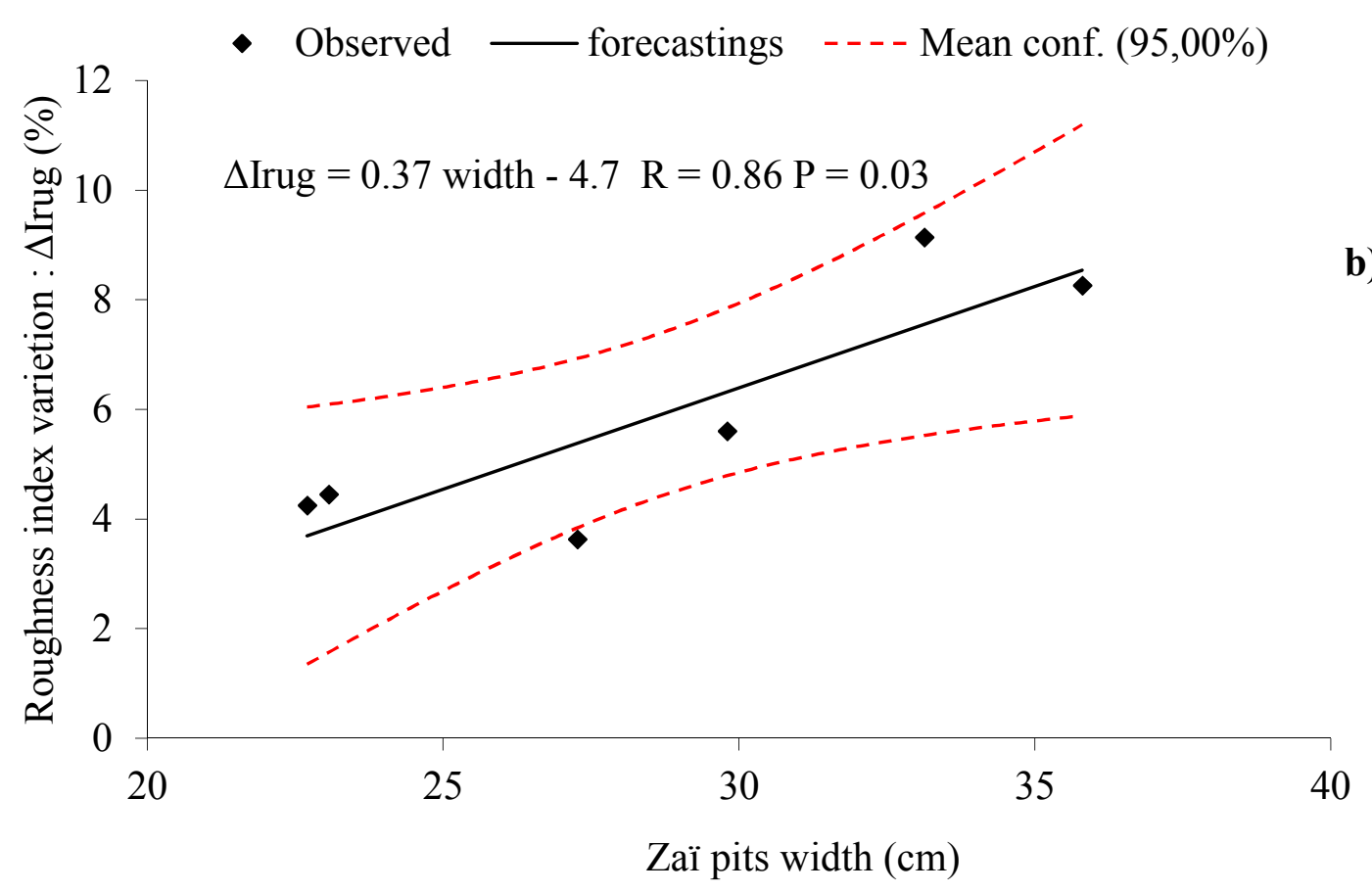

Figure 7: Roughness increase according to the pits depth (a); Roughness increase according to the pit width ( b). $\Delta$ Irug: roughness index variation, R: regression coefficient, P: probability. 


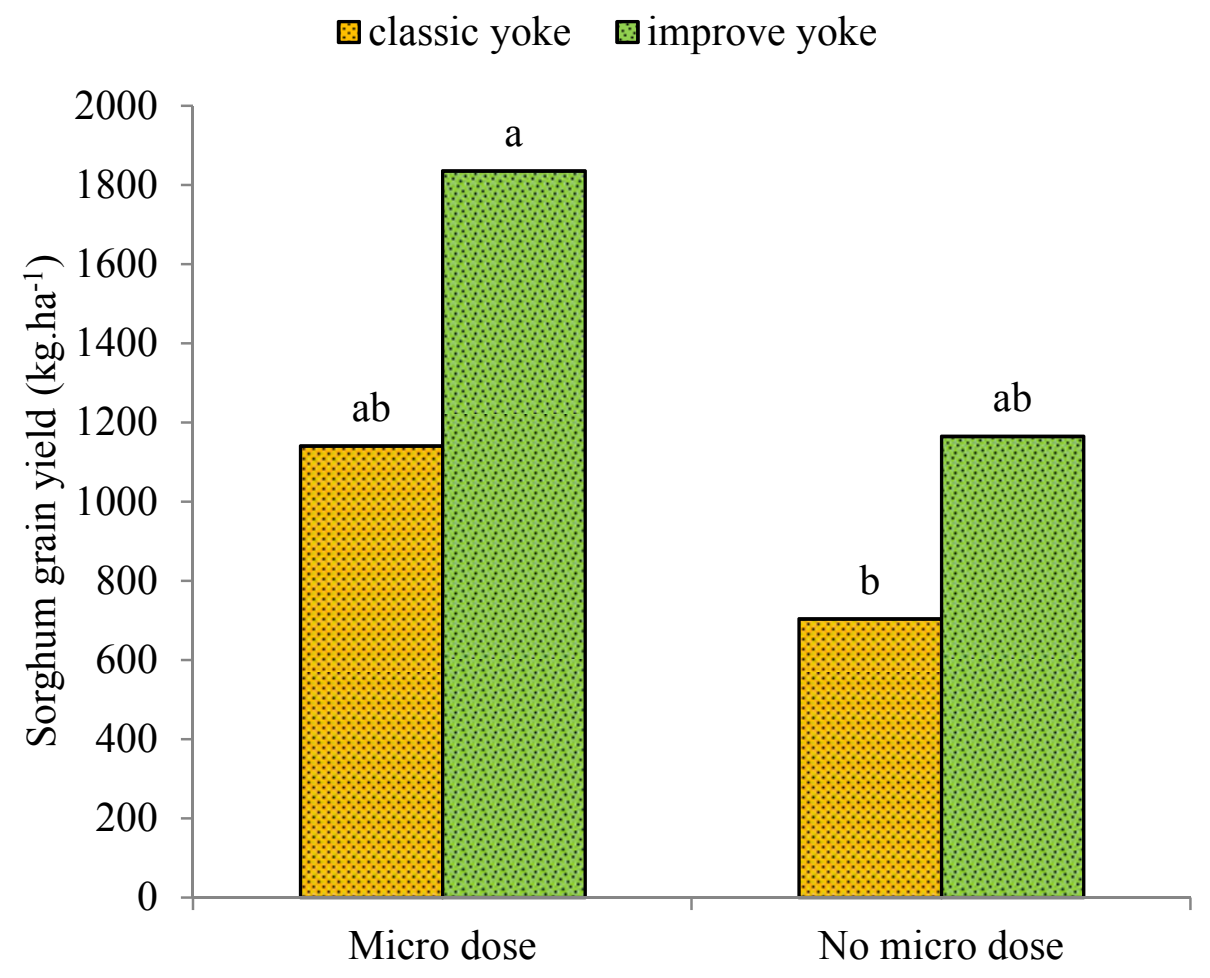

a)

四classic yoke improve yoke

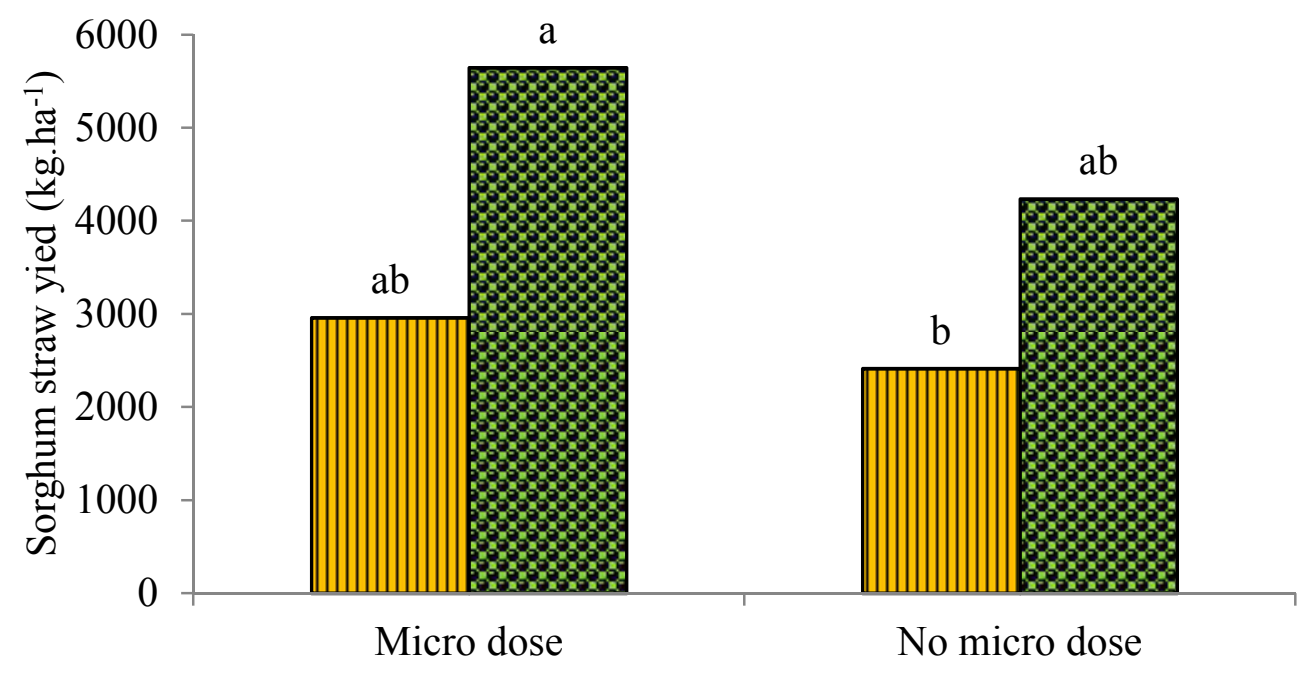

Figure 8: Sorghum Grain yield (a); sorghum straw yield (b). N and K test: a, ab, b, c, are groups of means significantly different at $\alpha=0.05$ level. 


\section{DISCUSSION}

\section{Increase of the traction capacity}

The study showed the difference that exists between the traction forces provided by using the improved and the classic yoke harness. The improved yoke allows to increase the traction force of the pair of oxen by $57 \%$. This would be due to the characteristics of the yoke: the cushions and rounded corners of yoke allow animals to avoid painful points during the traction and well breathe during tillage. During the traction with the classic yoke, relatively acute angles and the iron bars, create pain either by compression or by the heat. In addition to these points of pain, some classic yokes compress the trachea and the blood vessels of the draft animals, thus limiting their physiological capacity (Phaniraja and Panchasara, 2009) and can induce injuries to animals. For the donkey harness, there was not a significant difference between the traction forces of harness using the improved collar and those using the classic one. Donkey harness is not so comfortable because it does not have cushions but rags (Figures 4 a and 4 b). It is wide enough to allow animals breathing during tillage and does not create painful points at the traction period. The traction forces measured are around $25 \mathrm{daN}$ on average. In fact, this corresponds to the capacity of donkey whom supplies $25 \%$ of his weight in continuous tractive effort. The capacity of harness traction force, has direct effects on the tillage quality. The higher the capacity of traction is, the more the surface roughness increases. More efficient tillage with a better quality and roughness can alleviate runoff and erosion on the soil (Garcia Moreno et al., 2008). The width and the depth of the pits are higher $(10 \mathrm{~cm}$ depth and $33 \mathrm{~cm}$ width).

Efficient soil tillage is very important for crops sets in Sahelian regions where the first rains scarcity and their weakness compromise plant growth (Masson et al., 2014). Dry soil tillage induces a better water infiltration in the soil and moisture thus obtained is favorable to an early sowing on the plot tilled (Salé et al., 2014).

\section{Tool action on soil}

The greatest roughness index increase is obtained on improved yoke plots $(6.76 \%)$. This allows a good infiltration and better water conservation in the soil at the beginning of the rainy season (Lampurlanés and Cantero-Martunez, 2006; Garcia Moreno et al., 2011). The width of zaï pits is linked to the soil roughness by a positive relationship. More the soil roughness is high, more the width of the pit is large. This distinguishes the soils with low cohesion as sands and silts which will have a low pits width during dry soil tillage. Wet soils also will have a similar response because of the low cohesion forces. This is a limitation of the practice of mechanized zaï with tine IR12. It is recommended realizing tillage in dry soil, if not, the pits maybe too small and cannot contain enough compost for the proper plant development. However, for the silty and clayey soils, the water infiltration is often reduced and led to the reduction of the tool effects on roughness and water infiltration of this practice (Barro et al., 2005).

\section{Sorghum production}

The effect of harness with improved yoke led to increase Kapèlga grain yields from 
60 to $65 \%$, compared with plots where the harness with classic yoke has been used according the mineral fertilizer application or not. For the straw yields, the production increase is ranging from 74 to $91 \%$ according to the mineral fertilizer application or not. This practice is also favorable to soil fertility maintenance (Traoré et al., 2012). Beyond the agricultural production, a good harnessing helps to avoid injuries to the animals and also reduces the veterinary charges; the labor time with animals is also increasing because of their welfare. To increase production is an important factor for farmers in the way of getting income (Sermé et al., 2015); producers can get cash flows to invest in farm management and equipment (Mouazen et al., 2007). According to Gibigaye et al. (2012), the profitability in farms is calculated by taking into account the grain produced in the field; getting more grain yield by using of efficient harnessing is favorable to draft animal development in smallholders' farms.

\section{Conclusion}

As regard to the weakness of the traction force of harness, this study showed that the improved yoke provides a solution of traction force increase of $57 \%$ for oxen. The effect of this improved yoke is an increase in sorghum yield from 60 to $91 \%$ according the micro dose fertilizer application or not. The increase of the donkey harness, traction force during the dry soil tillage like mechanized zaï, suggests that they must be used in pairs with their classic collar. The improved yoke can be realized by the tradesmen. These tools of harnessing are propitious to the dissemination of mechanized zaï practice associated with a good agricultural practices for sorghum production increase.

\section{ACKNOWLEDGMENTS}

We thank the project for sustainable rural development (PDRD) and his entire team for the support that it made to the achievement of tests on the field. The thanks also go to the decentralized services of agriculture and to the producers who accompanied us in these tests on the different sites.

\section{COMPETING INTERESTS}

The authors declare that they have no competing interests.

\section{AUTHORS' CONTRIBUTIONS}

$\mathrm{AB}$ has contributed in the all study by choosing the experimental sites, the data collection, analysis and drafting the manuscript; CPK has contributed in variety choice, data analysis and drafting the manuscript; BY has contributed in data collection, analysis and drafting the manuscript.

\section{REFERENCES}

Arbonnier M. 2002. Arbres, Arbustes et Lianes des Zones Sèches d'Afrique de l'Ouest ( $2^{\text {ème }}$ édn). CIRAD MNHN, 573 p.

Barro A, Djamen P, Lahmar R, Simporé S. 2011. Evaluation des effets de la combinaison des techniques de travail du sol et de couverture végétale sur les caractéristiques du sol et la production agricole. Rapport INERA/SCAP, 55 p.

Barro A, Zougmoré R, Taonda SJB. 2005. Mécanisation de la technique du zaï manuel en zone semi-aride. Cahiers 
Agricultures, 14(6): 549-559. DOI: http://revues.cirad.fr/index.php/cahiersagricultures/article/viewFile/30550/3031 0.

FAO (Agriculture Organization of the United Nations). 2006. World reference base for soil resources: a framework for international classification, correlation and communication. Edt. 2006. Rome. www.fao.org/3/a-a0510e.pdf.

FAO (Agriculture Organization of the United Nations). 2008. Guide de formulation d'une stratégie de mécanisation agricole Etude de cas : stratégie nationale de la mécanisation agricole au Mali Rome. DOI:

http://www.fao.org/ag/ags/index_fr.html. García Moreno R, Díaz Álvarez MC, Tarquis AM, Barrington S, Saa Requejo A. 2008. Tillage and soil type effects on soil surface roughness at semiarid climatic conditions. Soil Till. Research, 98(1): 35-44. DOI: http://dx.doi.org/10.1007/ s40333-013-0246-z.

García Moreno R, Saa Requejo A, Durán Altisent J.M, Díaz Álvarez MC. 2011. Significance of soil erosion on soil surface roughness decay after tillage operations. Soil \& Tillage Research, 117: 49-54. DOI: http://dx.doi.org/ 10.1016/j.still.2011.08.002.

Gibigaye M, Tohozin YA, Sanon Y. 2012. Production du coton et adoption de la culture attelée dans la Commune de Malanville au nord du Bénin. Int. J. Biol. Chem. Sci., 6(4): 1729-1740. DOI: http://dx.doi.org/10.4314/ijbcs.v6i4.29.

Jester W, Klik A. 2005. Soil surface roughness measurement methods, applicability, and surface representation. Catena, 64(2-3): 174-192. DOI: http://dx.doi.org/10.1016/j.catena.2005.0 8.005 .

Kate S, Azontonde AH, Dagbenonbakin GD, et Sinsin B. 2016. Effets des changements climatiques et des modes de gestion sur la fertilité des sols dans la commune de Banikoara au nord-ouest du Benin. Int. J. Biol. Chem. Sci. 10(1): 120-133. DOI: http://dx.doi.org/10.4314/ ijbcs.v10i1.9.

Kiéma A, Nianogo AJ, Kaboré-Zoungrana CY, et Jalloh B. 2012. Effets des demilunes associées au scarifiage sur les productions fourragères en région sahélienne du Burkina Faso. Int. J. Biol. Chem. Sci., 6(6): 4018-4030. DOI: http://dx.doi.org/10.4314/ijbcs.v6i6.13.

Lampurlanés J, Cantero-Martunez C. 2006. Hydraulic conductivity, residue cover ADN soil surface roughness under different tillage systems in semiarid conditions. Soil and Tillage Research 85(1): 13-26. DOI: http://dx.doi.org/ 10.1016/j.still.2004.11.006.

Lëtzebuerger J. 2004. L'âne " Premier Fils $d u$ Paysan " Regards sur l'Introduction de la Traction Anise au Burkina Faso par les Jeunes Agriculteurs et Viticulteurs Luxembourgeois. Editeur, Lëtzebuerger Jongbaueren a Jongwënzer Service Tiers-Monde a.s.b.l. 5: Luxembourg; 45.

Lhoste Ph, Havard M, Vall E. 2010. La traction animale in Agricultures tropicales en poche. edt Quæ, CTA, Presses agronomiques de Gembloux.

Mason SC, Ouattara K, Taonda SJB, Palé S, Sohoro A, Kaboré D. 2014. Soil and cropping system research in semi-arid West Africa as related to the potential for conservation agriculture. International 
Journal of Agricultural Sustainability, 2(4): $1-15 . \quad$ DOI: http://dx.doi.org/10.1080/14735903.2014 .945319 .

Mouazen AM, Smolders S, Meresa F, Gebregziabher S, Nyssen J, Verplancke $\mathrm{H}$, Deckers J, Ramon H, De Baerdemaeker J. 2007. Improving animal drawn tillage system in Ethiopian highlands. Soil \& Tillage Research, 95: 218-230. DOI: http://dx.doi.org/10.1016/ j.still.2007.01.003.

Palé S, Mason SC, Taonda SJB. 2009. Water and fertilizer influence on yield of grain sorghum varieties produced in Burkina Faso. S. Afr. J. Plant Soil, 26(2): 91-97. DOI: $\quad$ http://dx.doi.org/10.1080/ 02571862.2009.10639939.

Phaniraja KL, Panchasara HH. 2009. Indian Draught Animals Power. Veterinary World, 2(10): 404-407. www.veterinaryworld.org/Vol.2/October

Salé A, Folefack DP, Obwoyere GO, Lenah wati N, Lendzemo WV, Wakponou A. 2014. Changements climatiques et déterminants d'adoption de la fumure organique dans la région semi-aride de Kibwezi au Kenya Int. J. Biol. Chem. Sci., 8(2): 680-694. DOI: http://dx.doi.org/10.4314/ijbcs.v8i2.24.

Sawadogo H, Bock L, Lacroix D, Zombre NP. 2008. Restoring soil potentialities using zaï and compost in Yatenga (Burkina Faso). Biotechnologie Agronomie Société Et Environnement, 12: 279-290. DOI: http://dx.doi.org/10.1016/ j.landurbplan.2013.05.004.

Sermé I, Ouattara K, Logah V, Taonda JB, Palé S, Quansah C, Abaidoo CR. 2015.
Impact of tillage and fertility management options on selected soil physical properties and sorghum yield. Int. J. Biol. Chem. Sci., 9(3): 1154-1170. DOI: http://dx.doi.org/10.4314/ijbcs. v9i3.2.

Traoré M, Lompo F, Ayuke F, Ouattara B, Ouattara K, Sédogo M. 2012. Influence des pratiques agricoles sur la macro faune du sol : cas de l'enfouissement de la paille et du fumier. Int. J. Biol. Chem. Sci., 6(4): 1761-1773. DOI: http://dx.doi.org/10.4314/ijbcs.v6i4.31.

Zougmoré R, Gnankambary Z, Guillobez S, Stroosnijder L. 2002. Effect of stone rows on soil chemical characteristics under continuous sorghum cropping in semiarid Burkina Faso. Soil \& Tillage Research, 66: 47-53. DOI: http://dx.doi.org/10.1007/s10705-0050531-0.

Zougmoré R, Mando A, Stroosnijder L. 2004. Economic benefits of combining soil and water conservation measures with nutrient management in semiarid Burkina Faso. Nutrient Cycling in Agroecosystems, 70: 261-269. DOI: http://dx.doi.org/10.1007/s10705-0069063-5.

Zougmoré R, Mando A, Stroosnijder L. 2008. Benefits of integrated soil fertility and water management in semi-arid West Africa: an example study in Burkina Faso. Nutrient Cycling in Agroecosystem, 88(1): 17-27. DOI: http://dx.doi.org/10.1007/s10705-0089191-1. 